\title{
REPLACEMENT OF COARSE AGGREGATE WITH STEEL SLAG IN HOT MIX ASPHALT
}

\author{
Pramukh N ${ }^{1}$, Jayadeva M N², Rahul Sona $\mathrm{H} \mathrm{R}^{3}$, S Shashank ${ }^{4}$, Anand Sagar ${ }^{5}$ \\ ${ }^{1}$ Assistant Professor, Department of Civil Engineering, JSS Academy of Technical Education, Bengaluru, Karnataka \\ ${ }^{2}$ Under Graduate Student, Department of Civil Engineering, JSS Academy of Technical Education, Bengaluru, \\ Karnataka \\ ${ }^{3}$ Under Graduate Student, Department of Civil Engineering, JSS Academy of Technical Education, Bengaluru, \\ Karnataka \\ ${ }^{4}$ Under Graduate Student, Department of Civil Engineering, JSS Academy of Technical Education, Bengaluru, \\ Karnataka \\ ${ }^{5}$ Under Graduate Student, Department of Civil Engineering, JSS Academy of Technical Education, Bengaluru, \\ Karnataka
}

\begin{abstract}
Flexible pavement is a structure consisting of a mixture of asphaltic or bituminous material and aggregates placed on a bed of compacted granular material of suitable nature in layers over the subgrade. The pavement should possess some characteristics such as riding quality, adequate skid resistance, favorable light reflecting characteristics, and low noise pollution. The main aim is to distribute of vehicular load to sub-grade. Hot mix asphalt (HMA) is a merger of $95 \%$ stone, sand, or gravel bound together by asphalt cement. Steel slag is a byproduct of the steel making process. The use of Steel slag in HMA can have a large economical, environmental, and engineering impact in pavement construction. Introduction of steel slag as aggregates reduces the demand for primary aggregates in nearby areas allowing the preservation of resources and reducing the indirect environmental impact caused by quarrying activities.
\end{abstract}

Keywords: Hot Mix Asphalt, Steel slag

\section{INTRODUCTION}

Bituminous concrete mixture is a combination of aggregate and binder. The aggregate acts as the structural skeleton of the pavement and bitumen acts as the glue of the mixture. The properties of the aggregate have direct and significant effect on the performance of the pavement. The utilization of industrial by-products and recycled materials in road construction as secondary and alternative materials has gained widespread acceptance and is becoming more important. The demands for industrial by-products and recycled materials are increasing every year. Using industrial by-products in pavement engineering not only provides construction materials with possible savings over new materials, but it also reduces demands on natural construction materials. It also can protect the environment and save money through reducing the amount of waste materials requiring disposal. The use of secondary aggregates like steel slag is increasing. It is still very limited if comparison is made with use of primary crushed stone aggregate. The resulting large quantities of slag produced and their potential impact on the environment have prompted materials scientists and civil engineers to explore the technically-sound, cost effective and environmentallyacceptable use of a wide range of slag in civil and highway construction.

\section{CHARACTERIZATION OF MATERIALSAND METHODOLOGY}

\subsection{Characterization of Aggregates}

Aggregates used in project work was collected at quarry in Anjanapura, Bengaluru. Themddleaggregate gradation for each type of mix was adopted as per MORTH specifications.

- Middle limit of gradation range: The nominal maximum size of this gradation is $13.2 \mathrm{~mm}$ for $\mathrm{BC}$. 
Aggregate gradation curve for Mid gradation rangs is plotted as below:

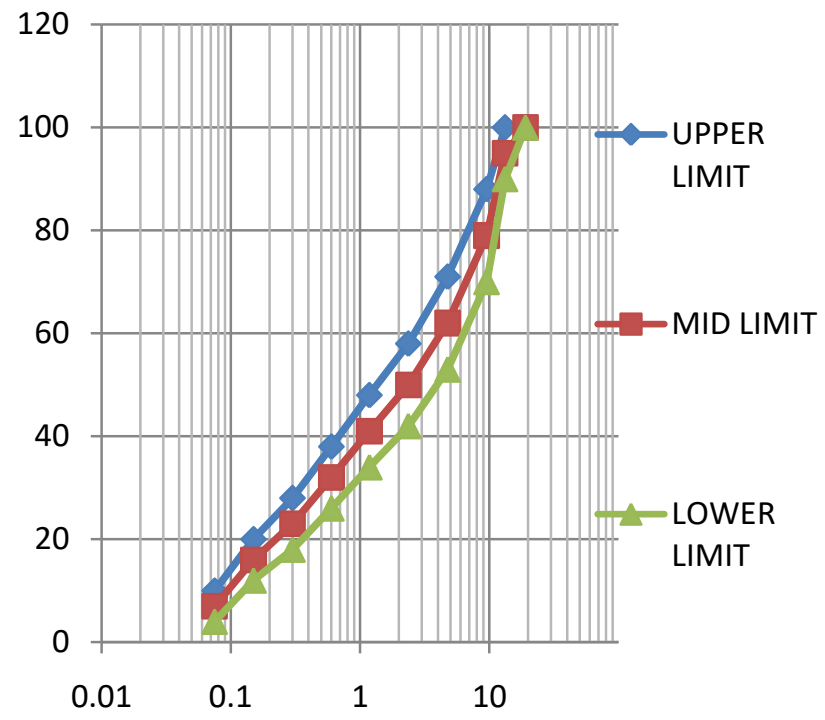

Fig-1: Gradation adopted

Basic properties of aggregates were determined in laboratory and are within the specification in accordance with MORTH.

Table 1: Basic properties of aggregates:

\begin{tabular}{|l|l|l|l|}
\hline $\begin{array}{l}\text { SI. } \\
\text { No }\end{array}$ & Test & Result & $\begin{array}{l}\text { MORTH } \\
\text { specification } \\
\text { Limits }\end{array}$ \\
\hline 1 & $\begin{array}{l}\text { Aggregate Impact } \\
\text { value }\end{array}$ & $22 \%$ & $24 \%$ max \\
\hline 2 & $\begin{array}{l}\text { Los Angeles } \\
\text { Abrasion value }\end{array}$ & $27 \%$ & $30 \% \max$ \\
\hline 3 & $\begin{array}{l}\text { Aggregate Crushing } \\
\text { value }\end{array}$ & $25 \%$ & $30 \%$ max \\
\hline 4 & $\begin{array}{l}\text { Specific gravity } \\
12.5 m m \text { down }\end{array}$ & 2.7 & - \\
\hline 5 & $\begin{array}{l}\text { Water absorption } \\
(\%)\end{array}$ & & - \\
\hline & $12.5 m m$ down & 0.5 & \\
\hline
\end{tabular}

\subsection{Characterization of Bitumen}

The type of binder used for preparation of bituminous mixture is VG-30 and this was tested for its physical properties and it satisfies all requirements as per MoRTH specification.
Table 2: Properties of VG - 30 grade bitumen

\begin{tabular}{|c|c|c|c|c|}
\hline $\begin{array}{l}\text { Sl } \\
\text { No }\end{array}$ & Test & Code & Results & $\begin{array}{l}\text { Requireme } \\
\text { nts as per } \\
\text { MORTH }\end{array}$ \\
\hline 1 & $\begin{array}{l}\text { Penetrati } \\
\text { on at } \\
25^{\circ} \mathrm{c} \\
(\mathrm{mm})\end{array}$ & IS 73:2006 & 65 & $50-70$ \\
\hline 2 & $\begin{array}{l}\text { Ductility } \\
\text { at } 25^{\circ} \mathrm{c} \\
(\mathrm{cm})\end{array}$ & IS 73:2006 & 85 & Min 75 \\
\hline 3 & $\begin{array}{l}\text { Softenin } \\
\mathrm{g} \text { point } \\
\left({ }^{\circ} \mathrm{c}\right)\end{array}$ & IS 73:2006 & 62 & $\operatorname{Min} 47^{\circ} \mathrm{c}$ \\
\hline 4 & $\begin{array}{l}\text { Specific } \\
\text { gravity at } \\
25^{\circ} \mathrm{c}\end{array}$ & IS 73:2006 & 1.01 & $0.97-1.02$ \\
\hline 5 & $\begin{array}{l}\text { Flash \& } \\
\text { Fire } \\
\text { point } \\
\left({ }^{\circ} \mathrm{c}\right)\end{array}$ & IS 73:2006 & $\begin{array}{l}285^{\circ} \mathrm{C} \\
310^{\circ} \mathrm{C}\end{array}$ & $\begin{array}{l}\operatorname{Min} 220^{\circ} \mathrm{c} \\
\operatorname{Min} 270^{\circ} \mathrm{c}\end{array}$ \\
\hline
\end{tabular}

\subsection{Characterization of Steel Slag}

Table 3: Properties of steel slag.

\begin{tabular}{|l|l|l|l|}
\hline $\begin{array}{l}\text { SI. } \\
\text { No }\end{array}$ & Test & Result & $\begin{array}{l}\text { MORTH } \\
\text { specification } \\
\text { Limits }\end{array}$ \\
\hline 1 & $\begin{array}{l}\text { Aggregate Impact } \\
\text { value }\end{array}$ & $25 \%$ & $45 \%$ max \\
\hline 2 & $\begin{array}{l}\text { Los Angeles Abrasion } \\
\text { value }\end{array}$ & $24 \%$ & $30 \% \max$ \\
\hline 3 & $\begin{array}{l}\text { Aggregate Crushing } \\
\text { value }\end{array}$ & $30 \%$ & $30 \%$ max \\
\hline 4 & Specific gravity & 3.24 & $2.1-3.2$ \\
\hline 5 & Water absorption $(\%)$ & & \\
\hline & $12.5 \mathrm{~mm}$ down & 1.5 & Max 5\% \\
\hline
\end{tabular}

\section{OPTIMUM BITUMEN CONTENT (OBC)}

Optimum Bitumen content was determined for Middle limit gradation with Combined Flakiness and Elongation Indices of $30-35 \%$ and results are tabulated: 
Table 4: $\mathrm{OBC}$ results

\begin{tabular}{|l|l|l|l|}
\hline \multicolumn{1}{|c|}{$\begin{array}{c}\text { Marshall } \\
\text { Properties }\end{array}$} & $\begin{array}{c}\text { Virgin } \\
\text { mix }\end{array}$ & $\begin{array}{c}\mathbf{5 0 \%} \\
\text { replace- } \\
\text { ment }\end{array}$ & $\begin{array}{c}\mathbf{1 0 0 \%} \\
\text { replace- } \\
\text { ment }\end{array}$ \\
\hline Bulk Density g/cc & 2.325 & 2.372 & 2.383 \\
\hline $\begin{array}{l}\text { Optimum } \\
\text { bitumen content } \\
(\mathbf{0})\end{array}$ & 5.8 & 5.5 & 5.3 \\
\hline $\begin{array}{l}\text { Voids in mineral } \\
\text { aggregate (VMA) } \\
(\%)\end{array}$ & 15.95 & 16.52 & 18.43 \\
\hline $\begin{array}{l}\text { Air voids } \\
\{\text { V }\} \text { (\%) })\end{array}$ & 3.45 & 3.6 & 5.08 \\
\hline $\begin{array}{l}\text { Voids filled with } \\
\text { bitumen }\{\text { VFB }\} \\
(\%)\end{array}$ & 78.39 & 78.21 & 72.44 \\
\hline Stability (KN) & 20.9 & 21.8 & 18 \\
\hline
\end{tabular}

\section{COMPARITIVE PLOTS FOR MARSHALL}

PROPERTIES FOR DIFFERENT MIXES AT OBC

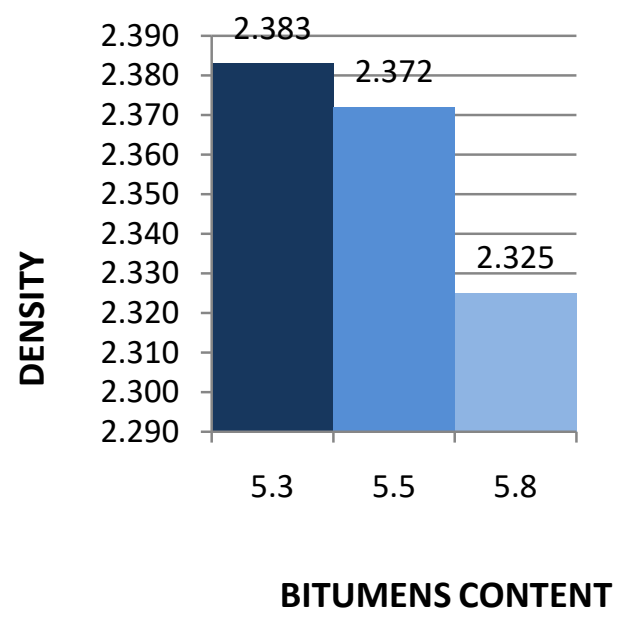

\section{8 -VIRIGIN \\ 5.5-50\% REPLACEMENT \\ 5.3-100\% replacement}

Fig 2: Biumen vs Density

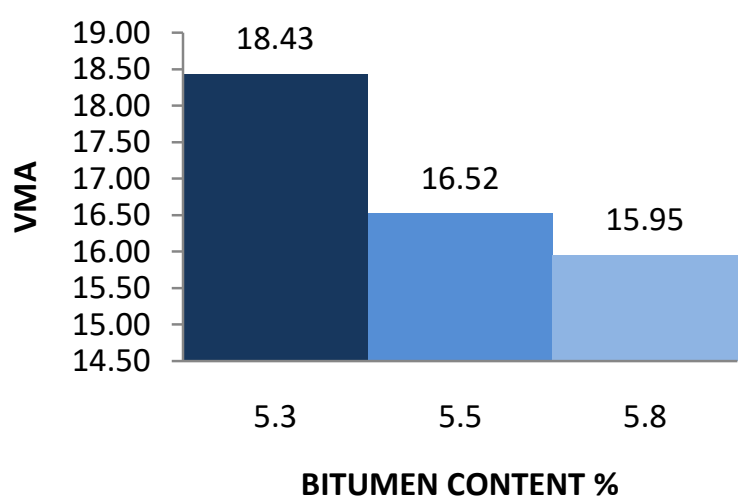

5.8 -VIRIGIN

5.5-50\% REPLACEMENT

5.3-100\% replacement

Fig 3: Bitumen vs VMA
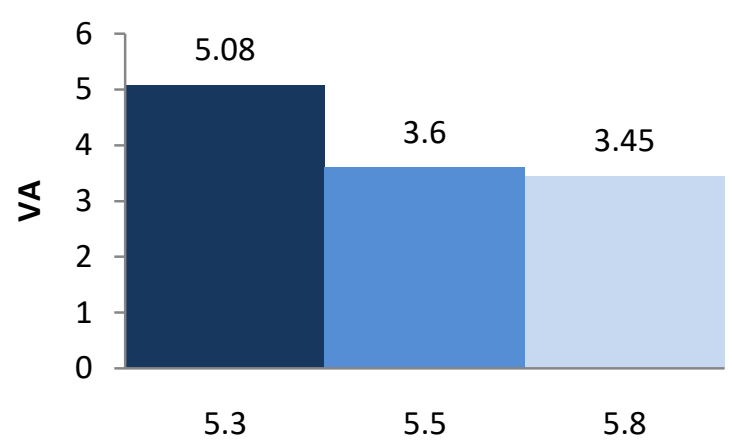

BITUMEN CONTENT \%

5.8 -VIRIGIN

5.5-50\% REPLACEMENT

5.3-100\% replacement

Fig 4: Biumen vs Air Voids

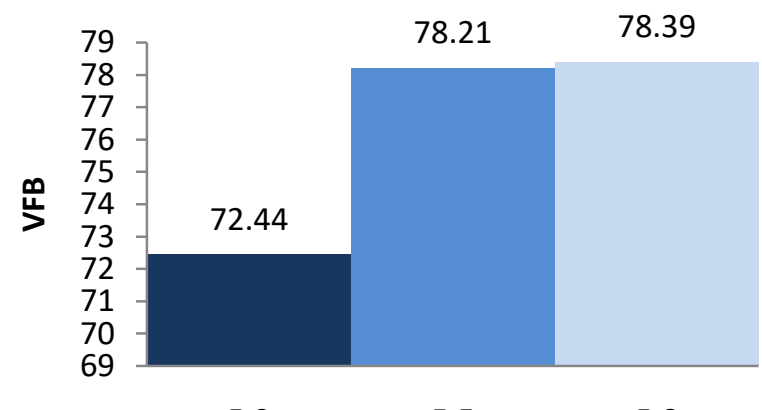

5.8 -VIRIGIN

BITUMEN CONTENT \%

5.5-50\% REPLACEMENT

5.3-100\% replacement

Fig 5: Biumen vs VFB 


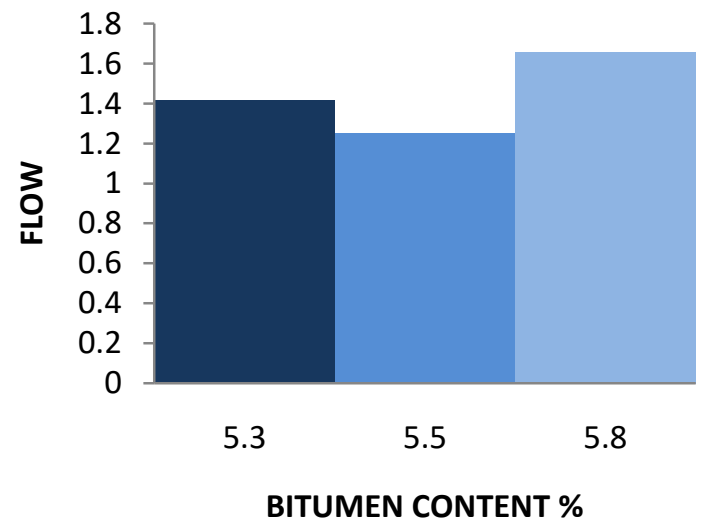

5.8-VIRIGIN

5.5-50\% REPLACEMENT

5.3-100\% replacement

Fig 6: Biumen vs Flow

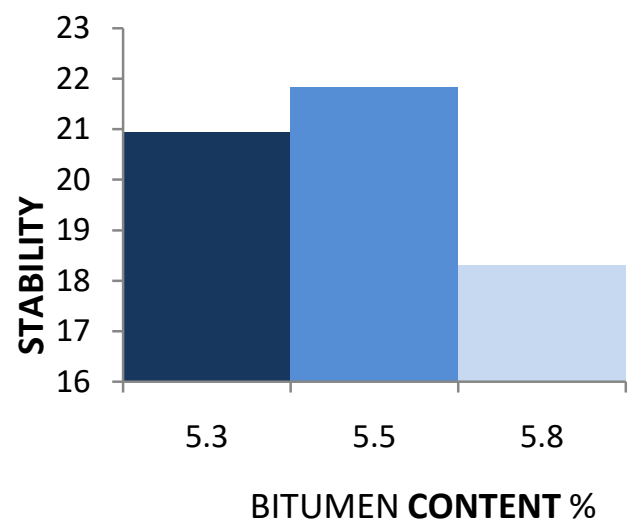

5.8-VIRIGIN

5.5-50\% REPLACEMENT

5.3-100\% replacement

Fig 7: Biumen vs Stability

\section{CONCLUSION}

- $\quad$ This study revealed that the use of steel slag as a replacement to coarse aggregate in Hot Mix Asphalt greatly improves its density, stability and strength.

- This study also shows that the use of steel slag in HMA reduces the optimum bitumen content, thus making the flexible pavement construction more economical and eco-friendly.

- $\quad$ The incorporation of steel slag in flexible pavement construction improves its efficiency, serviceability and durability.

- It also reduces the negative impact on environment caused due to overexploitation of natural sources of coarse aggregate, thus making the flexible pavement construction practices more sustainable.

\section{ACKNOWLEDGEMENT}

We would like to thank our guide Mr. PRAMUKH N, Assistant Professor, HOD \& Staff, Department of Civil Engineering, JSSATE, Bengaluru, Karnataka, for their constant encouragement, guidance and support, which enabled me to complete this project.

We would like to thank our parents for their continuous support throughout our life.

\section{REFERENCES}

[1] Ministry of Road Transport and Highways ( MoRTH $-5^{\mathrm{TH}}$ Revision)

[2] Principles and practises of Highway Engineering - L. R Kadiyali, N. B Lal.

[3] IS 73-2006.

[4] IS:2386 Part 4.

[5] C. Kambole, P. Paige - Green, W. K. Kupolati, J. M. Ndambuki, A.O Adeboje, Basic oxygen furnace slag for road pavements, ELSEVIER, Construction and Building Materials 148 (2017) 618-631.

[6] Amir Kavussi, MortezaJaliliQazizadeh, Fatigue characterization of asphalt mixes containing electric arc furnace steel slag subjected to long term aging, ELSEVIER, Construction and Building Materials 72 (2014) 158-166.

[7] M. Arabani, A. R. Azarhoosh, The effect of recycled concrete aggregate and steel slag on the dynamic properties of Asphalt mixes, ELSEVIER, Construction and Building Materials 35 (2012) 1-7.

[8] M. Skaf, V. Ortega-Lopez, J. A. Fuente-Alonso, A. Santamaria, J.M. Manso, Ladle furnace slag in asphalt mixes, ELSEVIER, Construction and Building Materials 122 (2016) 488-495.

[9] Deng-Fong Lin, Liang-Hsiungchou, Yu-Kai wang, Performance evaluation of asphalt concrete test road partially paved with industrial waste, ELSEVIER, Construction and Building Materials 78 (2015) 315323.

[10] Shih-Huang Chen, Deng-Fong Lin, Huan-Lin Luo, Zi-Yang Lin, Application of reclaimed basic oxygen furnace slag asphalt pavement in road base aggregate, ELSEVIER, Construction and Building Materials 157 (2017) 647-653. 